\title{
LOS DONES PREVISIBLES DE STELLA DÍAZ VARÍN*
}

Jénifer Díaz Faúndez

"Y en esto soy enfático. Creo, y lo digo sin pudores, que casi nadie conoce la obra de Stella Díaz Varín." El eco de las palabras del poeta y crítico Andrés Morales todavía pesan sobre esta poeta. Cuesta entender cómo Díaz Varín (1926-2006) sigue escondida detrás de la sombra de los mismos nombres que la veneraron (los mandragoristas, Lihn, Teillier, e incluso el mismo Neruda). Es lamentable que el carácter crítico y transgresor de Stella con su entorno la haya elevado al puesto de mito urbano, pero al mismo tiempo la haya difuminado del canon -o "listado"- literario chileno: se reconoce su figura, no así su poesía. Por lo mismo, revisitar el cuarto de sus poemarios, Los dones previsibles, constituido por un total de 27 poemas, representa un ajuste de cuentas con el olvido en que ha caído.

En Los dones previsibles la poeta presenta sus grandes temas, y, en un viaje desde lo íntimo a lo más abarcador, ella recorre desde su biografía hasta las principales problemáticas que observa en el ser humano: preguntas sobre la razón de la existencia, el carácter sagrado de esta y el conflicto entre la vida y la muerte. Resaltan poemas notables tales como "La casa", donde una mujer encuentra cierta calma a la angustia de su vacío existencial, de su vida que bordea el abismo, cuando decide organizarla poéticamente para reconfigurar paralelamente su cuerpo y su hogar; o "Breve historia de mi vida", poema cuyo sujeto se configura como mujer a través de una autobiografía que se resume en una vida dedicada a trabajar por la muerte o bien comandar soldados que "siempre traen perdida la batalla." Estas imágenes se presentan indesligables de la militancia política e ideológica de la poeta, intransable pese a su quiebre con el partido comunista, o a su intento de asesinato durante la dictadura militar, el "tiempo del asco", como Stella lo denominó, tiempo durante el cual no publicó nada, volviendo a la escritura recién 33 años después con el poemario aquí reseñado.

Al recordar el pasado ideológico de la poeta, cuesta no pensar en las entrevistas donde declaró sus principios y creencias con la misma voz, fuerte y rasgada, con que recitaba sus poemas: "Yo creía y todavía creo que el hombre es salvado por el hombre... Yo dije que Dios no existe, por lo tanto el hombre salva al hombre." Díaz Varín fue una convencida existencialista. Talvez lo más grato de escucharla hablar, o de leer sus ideas, se encuentra en cómo manifiesta su fe por el hombre, sin siquiera dudar. En Los dones previsibles esta fe hila todo el texto en un gran relato y, a través de una de las metáforas más hermosas del poemario, configura lo sagrado en lo terrenal: el don, algo esencialmente divino, se vuelve previsible, observable desde lo común. A fin de cuentas, un don para Stella es todo aquello que percibimos, ya sea otra persona, la naturaleza o el mundo en sí, y lo sagrado de estos elementos reside en que existen, en que convivimos con ellos

* Díaz Varín, Stella, Los dones previsibles, Santiago: Editorial Cuarto Propio, 1992, págs. 24-25. 
día a día. La poeta, queriendo compartir su secreto, nos susurra al oído la verdad que esconden sus versos. Su poesía es así un campo de batalla contra el olvido humano, o mejor dicho, contra eso que el hombre no puede evitar, el olvido de lo que realmente hay que recordar.

Tras lo señalado, y para concluir, no puedo dejar de pensar que leer a Díaz Varín, pese al paso del tiempo, sigue siendo un descubrimiento. No solo es la voz femenina de la Generación del 50 en Chile, sino una de las más grandes voces de la poesía de este país - de aquellas que entendían la poesía como un canto:

Por sobre todas las cosas

El canto:

El mío, el tuyo,

El nuestro.

No hay

Sino un solo canto.

...pero que por sobre todo, es la gran poeta de las verdades-.

Santiago, Agosto 2011 